\title{
PENGARUH KOMITMEN ORGANISASI DAN KEPUASAN KERJA TERHADAP KINERJA KARYAWAN BPJS KESEHATAN CABANG LANGSA
}

\author{
Abdul Latief*, Syardiansah**, Muhammad Safwan*** \\ * Fakultas Ekonomi, Univ. Samudra, latief@unsam.ac.id \\ **Fakultas Ekonomi, Univ. Samudra, syardiansah@unsam.ac.id \\ ***Fakultas Ekonomi, Univ. Samudra, msafwan@gmail.com
}

\begin{abstract}
Abstrak
Penelitian bertujuan untuk mengetahui pengaruh komitmen organiasi dan kepuasan kerja terhadap kinerja karyawan BPJS Kesehatan Kota Langsa. Yang menjadi populasi pada penelitian ini adalah karyawan tetap pada BPJS Kesehatan Cabang Langsa yang berjumlah 31 responden. Teknik sampling yang digunakan dalam penelitian ini adalah non probability sampling menggunakan sampling jenuh. Metode analisis data menggunakan persamaan regresi linier berganda dengan bantuan software SPSS dilakukan uji $t$, uji F dan uji koefisien determinasi. Hasil regresi linear berganda diperoleh persamaan $Y=1,098+0,260 X 1+0,290 X 2$. Untuk membuktikan hipotesis secara parsial dilakukan uji t untuk masing-masing variabel, dimana variabel komitmen organisasi diperoleh $t$ sig $<5 \%(0,03<0,05)$ sehingga dapat dinyatakan bahwa komitmen organisasi berpengaruh signifikan terhadap kinerja karyawan BPJS kesehatan Kota Langsa. Variabel kepuasan kerja diperoleh $\mathrm{t}$ sig $<5 \%(0,04<0,05)$ sehingga dapat dinyatakan bahwa kepuasan kerja berpengaruh signifikan terhadap kinerja karyawan BPJS kesehatan Kota Langsa. Dan untuk membuktikan hipotesis secara simultan dilakukan uji $\mathrm{F}$, sehingga diperoleh $\mathrm{F}$ sig $<5 \%(0,00<0,05)$ sehingga dapat dinyatakan bahwa komitmen organisasi dan kepuasan kerja secara simultan berpengaruh signifikan terhadap kinerja karyawan BPJS kesehatan Kota Langsa. Serta dari hasil uji koefisien determinasi diperoleh sebesar 33,4\% komitmen organisasi dan kepuasan kerja mempengaruhi kinerja karyawan BPJS kesehatan Kota Langsa.
\end{abstract}

Kata Kunci: Komitmen Organisasi, Kepuasan Kerja dan Kinerja 


\begin{abstract}
Abstact
The study aimed to determine the effect of organizational commitment and job satisfaction on the performance of Langsa Health BPJS employees. The population in this study were permanent employees at the Langsa Health BPJS, which numbered 31 respondents. The sampling technique used in this study is non probability sampling using saturated sampling. The method of data analysis uses multiple linear regression equations with the help of SPSS software carried out $t$ test, $F$ test and the coefficient of determination. The results of multiple linear regression obtained by the equation $\mathrm{Y}=1,098+0,260 \mathrm{X} 1+0,290 \mathrm{X} 2$. To prove the hypothesis partially carried out t test for each variable, where the organizational commitment variable obtained $t$ sig $<5 \%(0.03<0.05)$ so that it can be stated that organizational commitment has a significant effect on the performance of BPJS health employees in Langsa City. Job satisfaction variables obtained $t$ sig $<5 \%$ $(0.04<0.05)$ so that it can be stated that job satisfaction has a significant effect on the performance of BPJS health employees in Langsa City. And to prove the hypothesis simultaneously the $\mathrm{F}$ test is carried out, so that $\mathrm{F}$ sig $<5 \%(0.00<0.05)$ can be stated that organizational commitment and job satisfaction simultaneously have a significant effect on the performance of BPJS employees in Langsa City. As well as the determination coefficient test results obtained by $33.4 \%$ organizational commitment and job satisfaction affect the performance of health workers BPJS Langsa City.
\end{abstract}

Keywords: Organizational Commitment, Job Satisfaction and Performance 


\section{PENDAHULUAN}

Untuk menjamin keberlangsungan sebuah perusahaan dalam mencapai tujuan serta visi misi yang telah dibuat harus selalu mampu bersaing dengan perkembangan dan tuntutan zaman. Saat ini bukan hanya faktor eksternal saja yang dapat mempengaruhi kinerja sebuah perusahaan, namun faktor internal lebih sangat memiliki pengaruh dalam peningkatan atau penurunan kinerja sebuah perusahaan. Misalnya dengan kepuasan yang didapat oleh karyawan selama berkerja dalam sebuah perusahaan, jika karyawan puas dengan bekerjaannya sangat tidak mungkin kinerja yang ditunjukkan selama bekerja pun akan semakin baik. Demikian pula halnya komitmen organisasi yang dimiliki oleh karyawan dalam sebuah perusahaan rendah tentu saja sangat memiliki pengaruh terhadap kinerja sebuah perusahaan.

Komitmen organisasi mencerminkan bagaimana seorang individu mengidentifikasikan dirinya sendiri dengan organisasi dan bagaimana individu tersebut terikat dengan tujuan organisasi. Karyawan yang memiliki komitmen terhadap organisasi, mengembangkan pola pandang yang lebih positif terhadap organisasi dan dengansenang hati tanpa paksaan mengeluarkan energi ekstra demi kepentinganorganisasi. Sehingga komitmen organisasi memiliki arti yang lebih dari sekedar kesetiaan yaitu keaktifan karyawan dalam bekerja serta memberikan kontribusi terhadap perusahaan. Karyawan yang memiliki komitmen organisasi dapat diketahui dari kesiapan dalam bekerja dan memiliki keinginan untuk bertahan bergabung di perusahaan dan hal ini berkaitan dengan kepuasan kerja karyawan pada organisasi.

Kinerja Sumber Daya Manusia yang menjadi karyawan pada perusahaan yang diharapkan berupa kualitas, kuantitas dan ketepatan waktu dalam menjalankan setiap tugas yang diberikan. Kinerja karyawan memberikan gambaran keberhasilan karyawan dalam menyelesaikan tugas-tugas yang telah diberikan secara umum dikatakan sebagai kinerja karyawan. Kinerja karyawan yang baik pada sebuah organisasi ini dapat disebabkan oleh adanya komitmen karyawan terhadap organisasi serta adanya kepuasan kerja. Komitmen organisasi sebagai keinginan karyawan untuk tetap mempertahankan keanggotannya dalam organisasi dan bersedia usaha yang tinggi demi pencapaian tujuan organisasi (Sopiah dalam Novita, Sunnuharjo dan Ruhana, 2016:40).

Kepuasan kerja yang merupakan perasaan positif karyawan tentang pekerjaan yang dikerjakan dan memberikan hasil yang baik. Ketika karyawan merasa puas terhadap perusahaan maka karyawan cenderung lebih efektif dalam memberikan kinerja pada perusahaan dan sebaliknya karyawan yang merasa kurang puas terhadap perusahaan cenderung kurang efektif dalam memberikan pekerjaan. Untuk itu dapat kiranya perusahaan memberikan perhatian terhadap kepuasan kerja karyawannya 
karenakaryawan yang kurang puas dapat menurunkan kinerja.Rasa kurang puas dapat diketahui dari karyawan yang malas berangkat ketempat kerja dan malas dalam melakukan pekerjaannya. Sedangkan karyawan yang merasa puas terhadap pekerjaannya biasanya karyawan lebih senang dalam melakukan pekerjaan serta akan menimbulkan komitmen terhadap organisasi.

Badan Penyelenggara Jaminan Sosial (BPJS) yang merupakan perusahaan yang bergerak dalam pemberian jasa asuransi. Untuk setiap jasa asuransi yang diberikan berkinerja baik tentu saja sangat terkait dengan kinerja yang diberikan oleh karyawan yang bekerja pada BPJS. Kinerja ini tentu saja banyak faktor yang mempengaruhinya beberapa diantaranya adalah kepuasan kerja yang dimiliki oleh karyawan dan komitmen organisasi dari karyawan itu sendiri. Kepuasan kerja ini bisa berdasarkan balas jasa yang diberikan oleh perusahaan kepada karyawan sesuai dengan apa yang diharapkan oleh karyawan atau pun dalam bentuk lain seperti sikap dan tempat karyawan bekerja yang memberikan kepuasan tersendiri dalam bekerja. Dengan adanya kepuasan ini biasanya komitmen karyawan terhadap organisasi pun akan tumbuh dengan subur sehingga memiliki sifat saling menguntungkan. Berdasarkan fenomena tersebut peneliti ingin mengkaji tentang Pengaruh Komitmen Organisasi dan Kepuasan Kerja terhadap Kinerja Karyawan BPJS Kesehatan Cabang Langsa.

\section{LANDASAN TOERI}

\section{Komitmen Organisasi}

Sopiah dalam Novita, Sunnuharjo dan Ruhana (2016:40) menyatakan komitmen organisasi sebagai keinginan karyawan untuk tetap mempertahankan keanggotannya dalam organisasi dan bersedia usaha yang tinggi demi pencapaian tujuan organisasi. Sedangkan Luthans dalam Novita, Sunnuharjo dan Ruhana (2016:40), menyebutkan bahwa komitmen organisasi adalah keinginan kuat untuk tetap sebagai anggota organisasi tertentu, keinginan untuk berusaha keras sesuai dengan keinginan organisasi dan keyakinan tertentu juga penerimaan nilai dan tujuan organisasi.

Menurut Wati (2013:5) komitmen organisasi adalah derajat sejauh mana keterlibatan seseorang dalam organisasinya dan kekuatan identifikasinya terhadap suatu organisasi tertentu. Komitmen organisasi juga ditandai dengan tiga hal, yaitu suatu kepercayaan yang kuat terhadap organisasi juga penerimaan terhadap tujuan-tujuan dan nilai-nilai sebuah organisasi, keinginan kuat untuk memelihara hubungan yang kuat dengan organisasi dan kesiapan serta kesediaan untuk menyerahkan usaha keras demi kepentingan organisasi. Namun Griffin (2014:15) menyatakan bahwa komitmen organisasi adalah sikap yang mencerminkan sejauh mana seorang individu mengenal dan terikat pada organisasinya. Sedangkan menurut Streers dalam Mu- 
nandar (2014:75), komitmen organisasi adalah sifat hubungan seorang individu dengan organisasi dengan memperlihatkan ciri-ciri menerima nilai dan tujuan organisasi, mempunyai keinginan berbuat untuk organisasi dan setia terhadap organisasi.

Sopiah dalam Nadapdap (2017:2) menyatakan ada empat faktor yang mempengaruhi komitmen karyawan pada organisasi, yaitu:

1. Faktor personal, misalnya usia, jenis kelamin, tingkat pendidikan, pengalaman kerja dan kepribadian.

2. Karakteristik pekerjaan, misalnya lingkup jabatan, tantangan, konflik, peran, dan tingkat kesulitan dalam pekerjaan.

3. Karakteristik struktur, misalnya besar/kecilnya organisasi, bentuk organisasi (sentralisasi/desentralisasi), kehadiran serikat pekerja;

4. Pengalaman kerja. Pengalaman kerja karyawan sangat berpengaruh terhadap tingkat komitmen karyawan pada organisasi.

Robbins dalam Novita, Sunnuharjo dan Ruhana (2016:40) mengelompokan komitmen organisasi dalam tiga indikator yang terpisah, yaitu :

1. Affective commitmen (Komitmen Afektif). Perasaan emosional untuk organisasi dan keyakinan dalam nilai-nilainnya.

2. Continuance commitment (Komitmen Berkelanjutan). Nilai ekonomi yang dirasa dari bertahan dalam suatu organisasi bila dibandingkan dengan meninggalkan organisasi tersebut.

3. Normative commitment (Komitmen Normatif). Kewajiban untuk bertahan dalam organisasi untuk alasan moral dan etis.

\section{Kepuasan Kerja}

Wibowo (2014:413) menyatakan kepuasan kerja adalah sikap umum terhadap pekerjaan seseorang yang menunjukkan perbedaan antara jumlah penghargaan yang diterima pekerja dan jumlah yang mereka yakini seharusnya mereka terima. Menurut Tunggal (2012:91) kepuasan kerja adalah suatu perasaan yang menyokong atau tidak menyokong diri karyawan yang berhubungan dengan pekerjaannya maupun dengan kondisi dirinya. Perasaan yang berhubungan dengan pekerjaan melibatkan aspek-aspek seperti upah atau gaji yang diterima. Rivai dan Sagala (2011:856) menyatakan bahwa kepuasan kerja pada dasarnya merupakan sesuatu yang bersifat individu memiliki tingkat kepuasan yang berbeda-beda sesuai dengan sistem nilai yang berlaku pada dirinya. Makin tinggi penilaian terhadap kegiatan yang dirasakan sesuai dengan keinginan individu, maka makin tinggi kepuasannya terhadap kegiatan tersebut.

Namun Mangkunegara (2015:117) menyatakan bahwa kepuasan kerja adalah suatu perasaan yang menyokong/tidak menyokong diri pegawai yang berhubun- 
gan dengan pekerjaannya maupun dengan kondisi dirinya. Dan menurut Sunyoto (2013:26), kepuasan kerja (job satisfaction) adalah keadaan emosional yang menyenangkan atau menyenangkan di mana para karyawan memandang pekerjaannya.

Sedangkan Hasibuan (2016:202) menyatakan kepuasan kerja adalah sikap emosional yang menyenangkan dan mencintai pekerjaannya. Sikap ini dicerminkan oleh moral kerja, kedisiplinan dan prestasi kerja.kepuasan kerja dinikmati dalam pekerjaan, luar pekerjaan dan kombinasi dalam dan luar pekerjaan. Kepuasan kerja dalam pekerjaan adalah kepuasan kerja yang dinikmati dalam pekerjaan dengan memperoleh pujian hasil kerja, penempatan, perlakuan, peralatan dan suasana lingkungan kerja yang baik. Karyawan yang lebih suka menikmati kepuasan kerja dalam pekerjaan akan lebih mengutamakan pekerjaannya daripada balas jasa walaupun jasa itu penting.

Menurut Rivai dan Sagala (2011:860), bahwa faktor-faktor yang mempengaruhi kepuasan kerja sangat banyak jumlahnya, seperti gaya kepemimpinan, produktivitas kerja, perilaku, locus of control, pemenuhan harapan penggajian dan efektivitas kerja.

Namun menurut Ghiselli dan Brown dalam Sunyoto (2013:29), faktor-faktor yang menimbulkan kepuasan kerja yakni:

1. Kedudukan

Orang beranggapan bahwa seseorang yang bekerja pada pekerjaan yang lebih tinggi akan merasa lebih puas dari pada yang berkedudukan lebih rendah.

2. Pangkat

Pada pekerjaan yang mendasar pada perbedaan tingkat golongan, sehingga pekerjaan memberikan kedudukan tertentu pada orang yang melakukannya.

3. Umur

Dinyatakan adanya hubungan antara kepuasan kerja dengan umur karyawan.

4. Mutu pengawasan

Kepuasan karyawan dapat ditingkatkan melalui perhatian dan hubungan yang baik dari pimpinan dan hubungan yang lebih baik dari pimpinan dan bawahan sehingga karyawan akan merasa bahwa dirinya merupakan bagian yang terpenting dari organisasi kerja tersebut.

Sedangkan menurut Mangkunegara (2015:120), bahwa ada dua faktor yang mempengaruhi kepuasan kerja, yaitu :

1. Faktor Pegawai yaitu, kecerdasan (IQ), kecakapan khusus, umur, jenis kelamin, kondisi fisik, pendidikan, pengalaman kerja, masa kerja, kepribadian, emosi, cara berpikir, persepsi, dan sikap kerja.

2. Faktor Pekerjaan, yaitu jenis pekerjaan, struktur organisasi, pangkat(golongan), kedudukan, mutu pengawasan, jaminan finansial, kesempatan promosi jabatan, interaksi sosial dan hubungan kerja. 
Menurut Allen dan Meyer dalam Novita, Sunuharjo dan Ruhana (2016:39), terdapat sejumlah indikator-indikator kepuasan kerja, yaitu:

1. Pekerjaan itu sendiri.

Kepuasan pekerjaan itu sendiri merupakan sumber utama kepuasan

2. Gaji

Upah dan gaji dikenal menjadi signifikan, tetapi kompleks secara kognitif dan merupakan faktor multidimensi dalam kepuasan kerja.

\section{Promosi}

Kesempatan promosi sepertinya memiliki pengaruh berbeda pada kepuasan kerja karena promosi memiliki sejumlah bentuk yang berbeda dan memiliki berbagai penghargaan.

4. Pengawasan

Pengawasan merupakan sumber penting lain dari kepuasan kerja.

5. Rekan kerja

Rekan kerja atau anggota tim yang kooperatif merupakan sumber kepuasan kerja yang paling sederhana pada karyawan secara individu.

6. Kondisi kerja

Efek lingkungan kerja pada kepuasan kerjasama halnya denan efek kelompok kerja.jika segalanya berjalan baik tidak ada masalah kepuasan kerja.

\section{Kinerja}

Suwatno dan Priansa (2011:196) menyatakan bahwa kinerja merupakan performance atau unjuk kinerja.Kinerja dapat pula diartikan sebagai prestasi kerja atau pelaksanaan kerja atau hasil unjuk kerja. Menurut Mangkunegara (2015:9) kinerja adalah hasil kerja secara kualitas dan kuantitas yang dicapai oleh seseorang karyawan dalam melaksanakan tugasnya sesuai dengan tanggung jawab yang diberikan kepadanya. Namun Gomes dalam Mangkunegara (2015:9), mengemukakan definisi kinerja karyawan sebagai, “Ungkapan seperti output, efesiensi secara efektivitas sering dihubungkan dengan produktivitas.

Menurut Notoatmodjo (2011:124), kinerja seorang tenaga kerja atau karyawan dalam suatu organisasi atau institusi kerja, dipengaruhi oleh banyak faktor, baik faktor dari dalam karyawan itu sendiri maupun faktor lingkungan atau organisasi itu sendiri. Sedarmayanti (2012:147) menyatakan kinerja adalah hasil kerja yang dapat dicapai seseorang atau sekelompok orang dalam seuatu organisasi sesuai dengan wewenang dan tanggung jawab masing-masing dalam upaya mencapai tujuan organisasi bersangkutan secara legal, tidak melanggar hukum dan sesuai dengan moral ataupun etika.Yang paling penting pada pengertian itu adalah prestasi yang dicapai oleh individu ataupun kelompok kerja sesuai dengan aturan yang berlaku yang telah ditetapkan oleh organisasi. Dan Wibowo (2012:7) menyatakan bahwa kinerja merupa- 
kan hasil pekerjaan yang mempunyai hubungan kuat dengan tujuan strategis organisasi, kepuasan konsumen, dan memberikan kontribusi pada ekonomi. Kinerja adalah merupakan implementasi dari rencana yang telah disusun tersebut, implementasi kinerja dilakukan oleh sumber daya manusia yang memiliki kemampuan, kompetensi, motivasi dan kepentingan.

Faktor-faktor kinerja menurut Timple dalam Mangkunegara (2015:15) terdiri dari faktor internal dan faktor eksternal. Faktor internal yaitu faktor yang dihubungkan dengan sifat-sifat seseorang. Faktor eksternal yaitu faktor yang mempengaruhi kinerja seseorang yang berasal dari lingkungan. Menurut Mangkunegara (2015:67) ada beberapa faktor yang mempengaruhi kinerja pegawai seperti kemampuan, motivasi.

1. Faktor Kemampuan

Secara psikologi kemampuan pegawai/karyawan terdiri dari kemampuan dalam hal kepintaran dan juga kemampuan dalam hal keahlian. Artinya karyawan yang memiliki IQ diatas rata-rata dengan pendidikan sehari-hari, maka ia akan lebih mudah mencapai kinerja yang diharapkan.

2. Faktor Motivasi

Motivasi terbentuk dari sikap seorang karyawan dalam menghadapi situasi kerja. Motivasi merupakan kondisi penggerakkan diri pegawai yang terarah untuk mencapai tujuan organisasi.

Menurut Tiffin dan Mc. Cornick dalam Gaffar (2012:37) ada dua variabel yang dapat mempengaruhi kinerja, yaitu:

1. Variabel Individu, meliputi: sikap, karakteristik, sifat-sifat fisik, imnat dan motivasi, pengalaman, umur, jenis kelamin, pendidikan, serta faktor individu lainnya.

2. Variabel Organisasi

a. Faktor fisik dan pekerjaan, terdiri dari: metode kerja, kondisi dan desain perlengkapan kerja, penataan ruang dan lingkungan fisik (penyinaran, temperature, dan fentilasi).

b. Faktor sosial dan organisasi, meliputi: peraturan-peraturan organisasi, sifat organisasi, jenis latihan dan pengawasan, sistem upah dan lingkungan sosial.

Kasmir (2016:189) menyatakan untuk mengukur kinerja dapat dilakukan melalui faktor-faktor yang mempengaruhi kinerja, terdiri dari:

1. Kemampuan dan keahlian

Merupakan kemampuan atau skill yang dimiliki seseorang dalam melakukan suatu pekerjaan.

2. Pengetahuan 
Pengetahuan adalah pengetahuan tentang pekerjaan. Seseorang yang memiliki pengetahuan tentangg pekerjaan secara baik akan memberikan hasil pekerjaan yang baik, demikian pula sebaliknya.

3. Rancangan kerja

Merupakan rancangan pekerjaan yang akan memudahkan karyawan dalam mencapai tujuannya.

4. Kepribadian

Yaitu kepribadian seseorang atau karakter yang dimiliki seseorang. Setiap orang memiliki kepribadian atau karakter yang berberbeda satu sama lainnya.

5. Motivasi kerja

Motivasi kerja merupakan dorongan bagi seseorang untuk melakukan pekerjaan.

6. Kepemimpinan

Kepemimpinan merupakan perilaku seorang pemimpin dalam mengatur, mengelola dan memerintah bawahannya untuk mengerjakan sesuatu tugas.

7. Gaya kepemimpinan

Merupakan gaya atau sikap seseorang pemimpin dalam menghadapi atau memerintahkan bawawahannya.

8. Budaya organisasi

Merupakan kebiasaan-kebiasaan atau norma-norma yang berlaku dan dimiliki oleh suatu organisasi atau perusahaan.

9. Kepuasan kerja

Merupakan perasaan senang atau gembira atau perasaan suka seseorang sebelum dan setelah melakukan pekerjaan.

10. Lingkungan kerja

Merupakan suasana atau kondisi di sekirta lokasi tempat bekerja.

11. Loyalitas

Merupakan kesetiaan karyawan untuk tetap bekerja dan membela perusahaan dimana tempatnya bekerja.

12. Komitmen

Merupakan kepatuhan karyawan untuk menjalankan kebijakan atau peraturan perusahaan dalam bekerja.

13. Disiplin kerja

Merupakan usaha karyawan untuk menjalankan aktivitas kerjanya secara sungguh-sungguh. 
Menurut Mangkunegara (2015:75) terdapat empat indikator pengukuran kinerja para karyawan atau pegawai perusahaan, diantaranya sebagai berikut:

1. Kualitas

Kualitas kerja adalah seberapa baik seorang karyawan mengerjakan apa yang seharusnya dikerjakan.

2. Kuantitas

Kuantitas kerja adalah seberrapa lama seorang pegawai bekerja dalam satu harinya.Kuantitas kerja ini dapat dilihat dari kecepatan kerja setiap pegawai itu masing-masing.

3. Pelaksanaan tugas

Pelaksanaan tugas adalah seberapa jauh karyawan mampu melakukan pekerjaannya dengan akurat atau tidak ada kesalahan.

4. Tanggung jawab

Tanggung jawab terhadap pekerjaan adalah kesadaran akan kewajiban karyawan untuk melaksanakan pekerjaan yang diberikan perusahaan.

\section{METODE}

Yang menjadi populasi pada penelitian ini adalah karyawan tetap pada BPJS Kesehatan Cabang Langsa yang berjumlah 31 responden. Teknik sampling yang digunakan dalam penelitian ini adalah non probability sampling menggunakan sampling jenuh sehingga seluruh populasi menjadi sampel dalam penelitian ini. Jenis data dalam penelitian ini yaitu data kualitatif dan kuantitatif. Data kualitatif pada penelitian ini berupa teori-teori dan keadaan umum BPJS Kesehatan Cabang Langsa. Data kuantitatif berupa jumlah karyawan dan data tanggapan responden atas pernyataan yang diajukan dan di ukur dengan skala likert. Sedangkan sumber data dalam penelitian ini merupakan data primer yang diperoleh dengan cara melakukan wawancara, observasi dan memberikan kuesioner pada objek penelitian yaitu karyawan BPJS Kesehatan Cabang Langsa.

Penelitian ini menggunakan analisis regresi linier berganda dengan model persamaan sebagai berikut:

$$
\mathrm{Y}=\mathrm{a}+\mathrm{b}_{1} \mathrm{X}_{1}+\mathrm{b}_{2} \mathrm{X}_{2}
$$

Dimana:

$\mathrm{Y} \quad=$ Kinerja

a $\quad=$ Konstanta

$\mathrm{X}_{1}=$ Komitmen Organisasi 
$\mathrm{X}_{2} \quad=$ Kepuasan kerja

$b_{1}, b_{2}=$ Koefisien regresi

\section{HASIL DAN PEMBAHASAN}

Berdasarkan hasil penyebaran kuesioner kepada 31 orang responden dan dilakukan pengolahan data dengan bantuan software SPSS, maka diperoleh persamaan linear berganda berdasarkan tabel 1 dibawah ini adalah: $Y=1,098+0,260 X 1+0,290 X 2$

Tabel 1

Coefficients

\begin{tabular}{|c|c|c|c|c|c|}
\hline & \multirow{2}{*}{ Model } & \multicolumn{2}{|c|}{ Unstandardized Coefficients } & \multirow{2}{*}{$\mathrm{t}$} & \multirow{2}{*}{ Sig. } \\
\hline & & B & Std. Error & & \\
\hline \multirow{3}{*}{1} & (Constant) & 1,098 & 6,500 & 169 & ,867 \\
\hline & Komitmen Organisasi & ,260 &, 118 & 2,199 & ,036 \\
\hline & Kepuasan kerja & ,290 & ,139 & 2,081 & ,047 \\
\hline
\end{tabular}

Dari hasil pengolahan data kemudian dilakukan uji t untuk membuktikan hipotesis secara parsial dan diperoleh nilai t sig variabel komitmen organisasi $<5 \%(0,03$ $<0,05)$ sehingga dapat dinyatakan bahwa komitmen organisasi berpengaruh signifikan terhadap kinerja karyawan BPJS kesehatan Kota Langsa dan hipotesis dapat diterima. Varibel kepuasan kerja diperoleh nilai t sig < 5\% $(0,04<0,05)$ sehingga dapat dinyatakan bahwa kepuasan kerja berpengaruh signifikan terhadap kinerja karyawan BPJS kesehatan Kota Langsa dan hipotesis dapat diterima.

Untuk menguji hipotesis secara simultan dilakukan uji $\mathrm{F}$ dengan bantuan software SPSS diperoleh hasil seperti yang ditampilkan pada tabel 2 berikut:

Tabel 2

Anova

\begin{tabular}{llccc}
\hline \multicolumn{1}{l}{ Model } & Mean Square & $\mathrm{F}$ & Sig. \\
\hline \multirow{2}{*}{1} & Regression & 47,338 & 7,035 &, 003 \\
& Residual & 6,729 & & \\
\hline
\end{tabular}

Dapat dilihat bahwa nilai $\mathrm{F}$ hitung $>\mathrm{F}$ sig $<5 \%(0,03<0,05)$ sehingga dapat dinyatakan bahwa komitmen organisasi dan kepuasan kerja secara simultan berpengaruh signifikan terhadap kinerja karyawan BPJS kesehatan Kota Langsa dan hipotesis dapat diterima.

Selanjutnya untuk mengukur seberapa jauh kemampuan model dalam men- 
erangkan variasi variabel digunakan hasil pengolahan dari software SPSS seperti yang ditunjukkan dalam tabel 3 berikut:

Tabel 1.3

Model Summary

\begin{tabular}{|c|c|c|}
\hline $\mathrm{R}$ & R Square & Adjusted R Square \\
\hline, $578^{a}$ &, 334 & ,287 \\
\hline
\end{tabular}

Terlihat bahwa nilai $\mathrm{R}^{2}$ sebesar 0,334 atau 33,4\%. Artinya sebesar 33,4\% variabel komitmen organisasi dan kepuasan kerja mempengaruhi kinerja karyawan BPJS kesehatan Kota Langsa dan sebesar 66,6\% dipengaruhi oleh variabel lain yang tidak masuk dalam penelitian ini.

\section{SIMPULAN}

Berdasarkan hasil penelitian dan pembahasan dalam penelitian ini, maka penulis mengemukakan simpulan sebagai berikut:

1. Dari hasil persamaan ditunjukkan bahwa komitmen organisasi dan kepuasan kerja berpengaruh positif terhadap kinerja karyawan BPJS Kesehatan Kota Langsa.

2. Hasil pengujian hipotesis secara parsial terhadap variabel komitmen organisasi diperoleh bahwa hipotesis diterima dengan nilai $t$ sig < 0,05. Dan pengujian hipotesis secara parsial terhadap variabel kepuasan kerja diperoleh bahwa hipotesis diterima dengan nilai $t$ sig $<0,05$. Sehingga dapat disimpulkan secara parsial komitmen organisasi dan kepuasan kerja berpengaruh signifikan terhadap kinerja karyawan BPJS Kesehatan Kota Langsa.

3. Hasil pengujian hipotesis secara simultan dengan uji $F$ diperoleh $F$ sig $<0,05$ sehingga dapat disimpulkan komitmen organisasi dan kepuasan kerja secara simultan berpengaruh signifikan terhadap kinerja karyawan BPJS kesehatan Kota Langsa.

4. Dan dari hasil uji koefisien determinasi $\left(R^{2}\right)$ menunjukkan bahwa komitmen organisasi dan kepuasan kerja mempengaruhi kinerja karyawan BPJS kesehatan Kota Langsa sebesar 33,4\% dan sisanya sebesar 66,6\% dipengaruhi oleh variabel lain yang tidak masuk dalam penelitian ini.

\section{PUSTAKA ACUAN}

Anjani Merysa, Hamidah Nayati Utami dan Arik Prasetya. 2014. Pengaruh Keselamatan dan Kesehatan Kerja Terhadap Kinerja Karyawan (Studi pada Karyawan Bagian Produksi PT. International Power Mitsui Operation and Maintenance Indonesia (IPMOMI) Paiton), Jurnal Adminsitrasi Bisnis, Vol. 9, No. 1, Hal 1-9 
Gaffar. 2012. Analisis Kinerja Karyawan Perusahaan, Artikel.Vol. 12, No. 01. Hal.30-46. Griffin, Ricky W. 2013. Perilaku Organisasi. Jakarta: SalembaEmpat.

Hasibuan, Malayu. 2016. Manajemen Sumber Daya Manusia. Edisi Revisi. Jakarta:BumiAksara.

Jariyati, Irhamatul. 2016. Pengaruh Kepuasan Kerja Terhadap Kinerja Karyawan PT. Bank Pembiayaan Rakyat Syariah (BPRS) Bhakti Sumekar Kabupaten Sumenep, Skripsi. Malang: Universitas Islam Negeri Maulana Malik Ibrahim.

Kasmir, 2016. Manajemen Sumber Daya Manusia. Jakarta: Raja Grafindo Persada.

Kartika, Ratu Gera Wita Usa. 2012. Pengaruh Kepuasan Kerja Terhadap Komitmen Organisasi pada Karyawan PT. Hellomotion Korpora Indonesia. Skripsi. Depok: Universitas Indonesia.

Mangkunegara, Anwar, Prabu. 2015. Manajemen Sumber Daya Manusia. Bandung: Remaja Rosda Karya.

Malthis Robert L dan Jackson JH. 2012. Human Resources Management. Edisi 10. Jakarta: Salemba Empat.

Marwansyah. 2012. Manajemen Sumber Daya Manusia. Edisi Kedua. Bandung: Alfabeta. Mondy, R. Wayne. 2014. Manajemen Sumber Daya Manusia. Jakarta: Salemba Empat. Munandar, Utami. 2014. Pengembangan Kreativitas Anak Berbakat. Jakarta: Rineka Cipta.

Nadapdap, Kristanty. 2017. Pengaruh Komitmen Organisasi Terhadap Kinerja Karyawan pada PT. Mitra Permata Sari, Jurnal Ilmiah Methonomi. Vol. 3. No. 1, Hal 1-9.

Notoatmodjo Soekijo. 2011. Pengembangan Sumber Daya Manusia. Jakarta: Rineka Cipta.

Novita, Bambang Swasto Sunuharo dan Ika Ruhana. 2016. Pengaruh Kepuasan Kerja dan Komitmen Organisasional Terhadap Kinerja Karyawan (Studi pada PT. Telekomunikasi Indonesia, Tbk Witel Jatim Selatan, Malang). Jurnal Administrasi Bisnis. Vol. 34, No.1 Hal. 38-46.

Putrana Bagus Asta Iswara, dan AA Sagung Kartika Dewi. 2016. Pengaruh Kepuasan Kerja dan Komitmen Organisasional Terhadap Organizatioal Citizenship Behaviour. Journal Of Managemet. Vol. 5, No.8 Hal. 1-29.

Rivai, Veithzal, dan Ella Jauvani Sagala. 2011. Manajemen Sumber Daya Manusia untuk Perusahaan. Jakarta: Rajawali Pers

Rosita, Titik dan Tri Yuniati. 2016. Pengaruh Kepuasan Kerja Terhadap Kinerja Karyawan dengan Komitmen Organisasional sebagai Variabel Intervening. Jurnal IImu dan RisetManajemen. Vol 5. No. 1 Hal 1-20.

Sedarmayanti. 2012. Sumber Daya Manusia dan Produktivitas Kerja. Bandung: Mandar 
Maju.

Situmorang, Syafrizal Helmi dan MuslichLufti. 2014. Analisis Data untuk Riset Manajemen dan Bisnis. Medan: USU Press.

Sugiyono. 2017. Metode Penelitian Kuantitatif, Kualitatif dan R\&B. Bandung: Alfabeta. . 2012. Statistik Untuk Penelitan. Bandung: Alfabeta

Sunyoto, Danang. 2013. Sumber Daya Manusia. Jakarta: PT. Caps

Suwatno dan Juni Priansa. 2011. Manajemen SDM dalam Organisasi Publik dan Bisnis. Bandung: Alfabeta.

Sofyandi, Herman. 2011. Manajemen Sumber Daya Manusia. Yogyakarta: Graha Ilmu.

Tunggal, Wijaya. 2012. Pengantar Manajemen. Bandung: Alfabeta

Wibowo. 2012. Manajemen Kinerja. Jakarta: PT Raja Grafindo Persada 